\title{
People's Perception about Quarantine and its Impact on Occupational Stress: Community-Based Online Survey Following Covid-19 Outbreak in India
}

\author{
Subhadeep Mukherjee ${ }^{1}$, Dr. Soumendra Bhattacharjee ${ }^{2}$ \\ Sahiba Sharma ${ }^{3}$, Anubrata Paul ${ }^{4}$ \\ ${ }^{1}$ PhD-Research Scholar, Centre for Management Studies Dibrugarh University, Assam. \\ ${ }^{2}$ Assistant Professor, Department. of Management, BIT Mesra, Ranchi (Noida Campus). \\ ${ }^{3}$ Assistant Professor, Panipat Institute of Engineering and Technology (Panipat). \\ ${ }^{4}$ PhD-Research Scholar, Centre for Drug Design, Discovery \& \\ Development (C4D), SRM University, Delhi-NCR.
}

\begin{abstract}
COVID-19 has caused havoc almost throughout the world and India is also a strong victim of the same as the number of infected/positive cases is increasing drastically day by day. Quarantine i.e. a restriction on the movement of people which is intended to prevent the spread of disease is an unpleasant experience for those who undergo it. Separation from the loved ones, loss of freedom, uncertainty over the disease status, and boredom can create dramatic effects. Occupational stress of Job Stress refers to the job-related nervousness and anxiety which affects the emotion and/or physical health of the people.
\end{abstract}

This paper is a modest attempt to understand the people's perception about quarantine and its impact on Occupational Stress due to the outbreak of COVID-19 in India.

Data have been collected from 159 respondents by circulating the questionnaire through electronic mode. The collected data have been analysed by applying Structural Equation Modelling (SEM).

The findings reveal that there is no significant impact on occupational stress by people's perception of quarantine.

Keywords: Quarantine, People's Perception, Occupational Stress, COVID-19, India.

\section{Introduction}

COVID-19 Global health emergency has forced the governments around the world to take strict actions and quarantine is one of them. It is the oldest and effective method of controlling communicable disease outbreaks. In December 2019 there was a cluster of pneumonia cases in China where investigations found that people were affected by unknown viruses, now named as novel coronavirus disease 2019 (COVID-19). COVID 19 is defined as an illness caused by a novel coronavirus now called severe acute respiratory syndrome coronavirus 2 (SARS-COV-2; formerly called 2019-nCOV), which was first identified as an outbreak of respiratory illness cases in Wuhan City, Hubei Province, China. It was initially reported to the WHO on December 31, 2019. On January 30, 2020, the WHO declared the COVID-19 outbreak a global health emergency. On March 11, 2020, the WHO declared COVID-19 a global pandemic, its first such designation since declaring H1N1 influenza a pandemic in 2009. Since then, it has spread in many countries around the world, with the World Health Organization declaring it a pandemic.

The coronavirus disease 2019 (namely COVID-19) caused by severe acute respiratory syndrome coronavirus 2 (SARS-COV-2) broke out in Wuhan, China, in December 2019, and spread rapidly to other provinces [1-3]. To effectively control the development of the epidemic, according to the decision of the Chinese government, the First Shelter Hospital for children in Wuhan, ChinaWuchang Shelter Hospital operated to treat the patients with confirmed mild disease. Currently, data on epidemiological and clinical characteristics of COVID-19 in children are limited [4-6]. 
Coronaviruses are a large group of viruses, consist of genetic materials surrounded by envelope and protein spikes which gives an appearance of the crown (in Latin Corona). There are different types of coronaviruses with a respiratory infection, or sometimes gastrointestinal infection. The clinical spectrum of illness varies from no symptoms or mild respiratory symptoms to severe, rapidly progressive pneumonia, acute respiratory distress syndrome, septic shock, or multi-organ failure resulting in death. Zoonotic coronaviruses have emerged in recent years to cause human outbreaks such as Coronavirus Disease 2019 (COVID-19), Severe Acute Respiratory Syndrome (SARS) and Middle East Respiratory Syndrome (MERS). An acute respiratory infection is caused by severe acute respiratory syndrome coronavirus 2 (SARS-COV-2). It was first identified in Wuhan City, Hubei Province, China, in December 2019. An acute viral respiratory tract infection is caused by SARSCOV. It was first identified in the Guangdong province of Southern China in 2002 and an acute viral respiratory tract infection is caused by MERS-COV. It was first identified in Saudi Arabia in 2012.

Coronaviruses are positive-single stranded, enveloped large RNA viruses that majorly infect humans as well as a wide range of animals. The agent of Severe Acute Respiratory Syndrome (SARS), the Human Coronavirus (HCOV), is an enveloped positive single-stranded RNA virus from the Coronaviridae family, which has a genome size of about $29.7 \mathrm{~kb}$. Fever, cough, and progressive breath failure associated with respiratory complication are the main terrible manifestations of SARS infection. Coronaviruses have four subfamilies which include alpha-, beta-, gamma- and delta subtypes. COVs are a large family of viruses that are common in various other species including camels, cattle, cats and bats. They range in the size of 60-80 nm with genome size varying between 26 and $32 \mathrm{~kb}$. Recombination rates of COVs are very high due to the ability to develop constant transcription errors and RNA Dependent RNA Polymerase (RDRP) jumps. Most of the RNA content have encoded viral polymerase, RNA synthesis materials, and two large non-structural polyproteins that are not involved in host response modulation. The other one-third of the genome portion codes for four structural proteins i.e. Spike (S), Envelope (E), Membrane (M) Nucleocapsid (N), and the other helper proteins.

The recent illness caused by SARS-COV-2 was termed COVID-19 by the WHO, the new acronym derived from "Coronavirus Disease 2019". The name was chosen to avoid stigmatizing the virus's origin in terms of population, geography, or animal associations. The current outbreak of the novel coronavirus (COVs) starting from December 2019 has been widely spread from the Hubei province of YChina to many other countries. The WHO emergency committee on January 2020 has declared a global health emergency based on the rate of increasing spread of the viral infection and also estimated the fatality rate of about $4 \%$.

Quarantine, an effective measure to control the spread of infectious disease is usually implemented during any outbreak or global health emergency. Effect of being quarantined has been identified as an antecedent of posttraumatic stress symptoms even after three years (Wu et al, 2009). However, in this study, we want to understand people's perception of quarantine and its impact on occupational stress.

Besides having adverse effects on psychological health and well-being of an individual when under quarantine, it is interesting to know how to quarantine is perceived by people, in general. During the hour of crises, it is important to survey people to know their perception of quarantine and understand its impact on occupational stress. Hence, the present study aims to understand the people's perception of quarantine and its impact on occupational stress during the outbreak of COVID-19 in India.

The present study is structured as: Firstly, the review method and hypothesis has been presented followed by the design and methodology of the study. Secondly, the results and findings have been presented followed by the conclusion of the study.

\section{Review Method}

The research method for the systematic literature review is presented as:

(1) According to the recommendations of Kitchen ham (2004), the research was conducted through the following steps: 
A. Planning review

$>$ Identifying the need for a review

$>$ Specifying research questions

$>$ Developing a review protocol

$>$ Evaluating review protocol

B. Conducting review

$>$ Identifying primary study

$>$ Selecting primary studies based on inclusion criteria

$>$ Data extraction and synthesis

C. Reporting the review

$>$ Specifying dissemination mechanisms

$>$ Formatting the main report

\section{(2) Keyword Search}

Firstly, the existing literature related to keywords quarantine perception and occupational stress has been used. Secondly, the authors have also used synonyms such as job stress, work stress. Lastly, we have used AND, OR and Wildcards for search: ("Occupational Stress" OR "Job Stress" OR "Work Stress" AND "Quarantine*” OR "Perception*")

\section{(3) Resources Searched}

The databases used for the search were: EBSCO, JSTOR, ProQuest, Emerald, and Google Scholar.

\section{(4) Study Selection Criteria}

The inclusion criteria consisted of studies that are related to the research question and written in English. Exclusion criteria include the duplicated studies, viewpoints or opinions, studies in progress.

\section{(5) Study Selection Process}

Two different reviewers have screened and selected the papers based on the inclusion criteria. The studies were evaluated based on the abstract and conclusion. Finally, relevant studies were used for further analysis.

Lastly, the quality of studies was assessed using a 5 point Likert scale of poor to excellent and later data synthesis and extraction has been performed.

\section{Theoretical Underpinnings}

Hypothesis and Research Gaps

Stress is directly linked to the leading causes of death in the world. Stress-related to work has been identified as a factor that contributes to high turnover (Avey, Luthans, \& Jensen, 2009), inefficiency (Arnetz, 2006), absenteeism (Darr \& Johns, 2008), lower job satisfaction (Flanagan \& Flanagan, 2002). Occupational Stress is defined as the stress that is derived from a direct outcome or interaction of a person's work or job (Campbell, 2006; Dhar and Dhar, 2010). Occupational stress widely spread into cultures and has become an upcoming trend to the developing countries of the world, specifically those with emerging and impending economies. According to Hawryluck et al. (2004), longer durations of quarantine were associated with an increased prevalence of PTSD symptoms. Acquaintance with or direct exposure to someone with a diagnosis of SARS was also associated with PTSD and depressive symptoms. Studies have been conducted that are related to post quarantine and quarantine effects on stress. However, no study has found the relationship between people's perception of quarantine and occupational stress. Factors related to occupational stress are still being identified. Based on earlier studies, we have found that no study has been done under the Indian 
context to understand the people's perception of quarantine and its impact on occupational stress. Hence, based on current literature and research gap, the following hypothesis has been formulated.

H1: There is a significant impact on the occupational stress by the people's perception of quarantine.

Design And Methodology: The present study has explored to understand the people's perception of quarantine and its impact on occupational stress during the outbreak of COVID-19 in India. It was descriptive in nature based on the survey method.

$>$ Sample Size: 159 employed professionals from different states of India.

$>$ Sampling Method: Snowball Sampling

$>$ Margin of Error: $\pm 5 \%$ is taken as the standard error.

$>$ Confidence Level: $90 \%$

Data Collection: In the present study data and information has been collected from both primary and secondary sources. To get an insight view of the scenario, both primary and secondary data has provided a good deal of information on the existing scenario and particularly the specific to quarantine and occupational stress.

$>$ Primary data was collected by the online feedback of the selected respondents during the survey through the 'Snowball Sampling Technique'. A structured questionnaire was administered online (Google Form) which also contains the covering letter explaining the purpose of the response from the selected respondents.

$>$ Secondary data was collected from various sources such as books, journals, reports, and other published sources.

Research Approach: The field study was conducted to study the people's perception of quarantine and its impact on occupational stress during the outbreak of COVID-19 in India. The responses were collected from March $28^{\text {th }}$ to April $30^{\text {th }} 2020$.

Measuring Instrument: Perception of Quarantine was measured by the Quarantine Scale of Shawn Tracy, C. et.al. (2009) \& Occupational Stress was measured by the PSS Scale Cohen, S. et.al (1983). The Quarantine Scale was constructed with 4 Nos of Variable i.e. Justification, Sanctions, Burdens \& Safeguard which consist of 20 items \& Occupational Stress was constructed with 5 items which were scored through 5 points Likert scale ranging from 1 (Strongly Agree) to 5 (Strongly Disagree).

Conceptual Framework: This study proposes an initial conceptual framework that examines the impact between Quarantine and Occupational Stress as mentioned below in Figure 1:

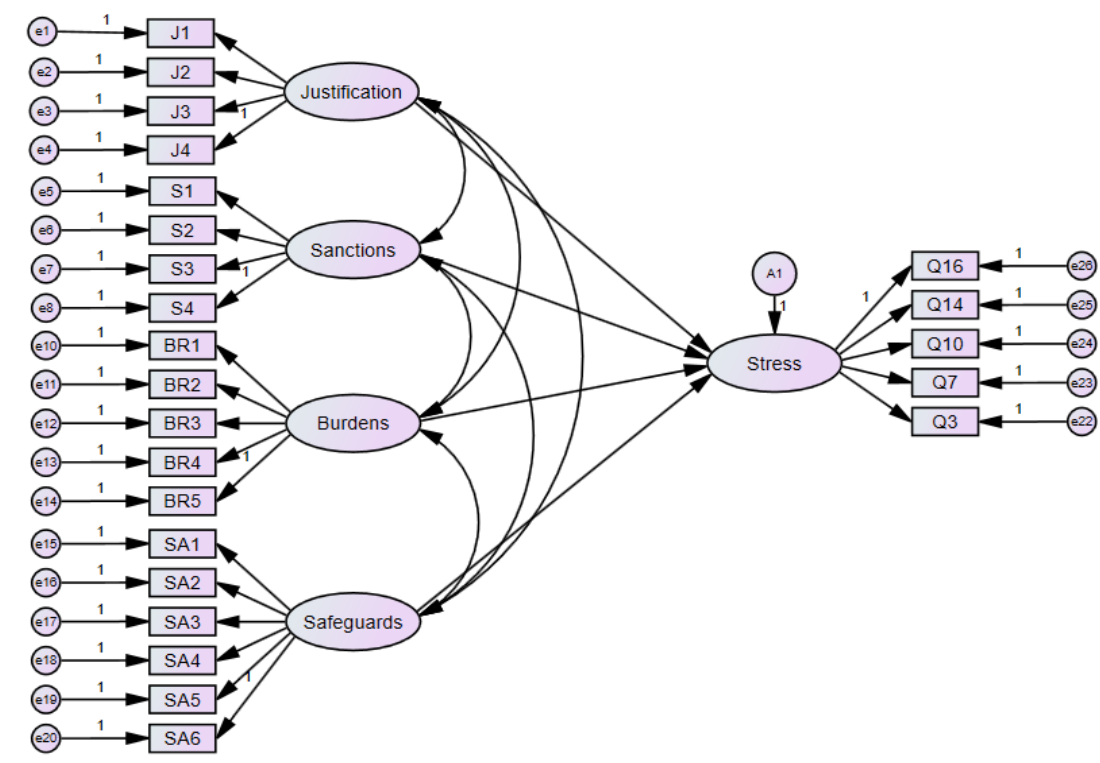




\section{Results and Findings}

Table-1 represents the socio-demographic representation of the respondents:

Table 1.Socio-Demographicic Profile of the Respondents

\begin{tabular}{|c|c|c|}
\hline \multirow[t]{4}{*}{ Age } & 25 Years To 35 Years & 106 \\
\hline & 36 Years To 45 Years & 32 \\
\hline & 46 Years To 55 Years & 18 \\
\hline & 56 Years \& Above & 3 \\
\hline \multirow[t]{2}{*}{ Gender } & Male & 126 \\
\hline & Female & 33 \\
\hline \multirow[t]{2}{*}{ Marital Status } & Unmarried & 79 \\
\hline & Married & 80 \\
\hline \multirow[t]{4}{*}{ No of Family Members } & $<3$ & 88 \\
\hline & $3-6$ & 52 \\
\hline & $7-9$ & 12 \\
\hline & $10>$ & 7 \\
\hline \multirow[t]{2}{*}{ Performing Work from } & Home & 152 \\
\hline & Office & 7 \\
\hline \multirow{2}{*}{ Education } & Masters and Above & 148 \\
\hline & Bachelor Degree & 11 \\
\hline \multirow{13}{*}{ Responses from Indian States } & Uttar Pradesh & 32 \\
\hline & Jharkhand & 28 \\
\hline & Assam & 22 \\
\hline & West Bengal & 20 \\
\hline & Tamil Nadu & 10 \\
\hline & Karnataka & 9 \\
\hline & Haryana & 7 \\
\hline & Panjab & 7 \\
\hline & Maharashtra & 6 \\
\hline & Odisha & 6 \\
\hline & New Delhi & 5 \\
\hline & Rajasthan & 4 \\
\hline & Chhattisgarh & 3 \\
\hline
\end{tabular}

$\mathrm{N}=159$ Respondents.

Source: Survey.

\section{Reliability Testing}

Table No 2 represents the reliability of the scale for Quarantine and Occupational Stress:

Table 2.Reliability Statistics

\begin{tabular}{|l|l|}
\hline Variable & Cronbach's Alpha \\
\hline Quarantine & .939 \\
\hline Occupational Stress & .820 \\
\hline
\end{tabular}

$\mathrm{N}=159$ Respondents.

Source: Survey.

As the alpha value of Quarantine is greater than 0.9 in Table-2 i.e. 0.943 , so the reliability of the scale can be considered as excellent. Similarly, the alpha value of Occupational Stress is greater than 0.8 in the Table-2 i.e. 0.820 , hence the reliability of the scale can be considered as good. The questionnaire was filled by 159 employed respondents from different part of the country to measure the impact of quarantine on occupational stress. 


\section{Confirmatory Factor Analysis}

Confirmatory factor analysis is a special case of Structural Equation Modeling SEM (Joreskog \& Sorborn, 2004). The confirmatory factor analysis was applied by using SPSS Amos 24.0 to the five factors extracted in the factor analysis as mentioned in Figure-2:

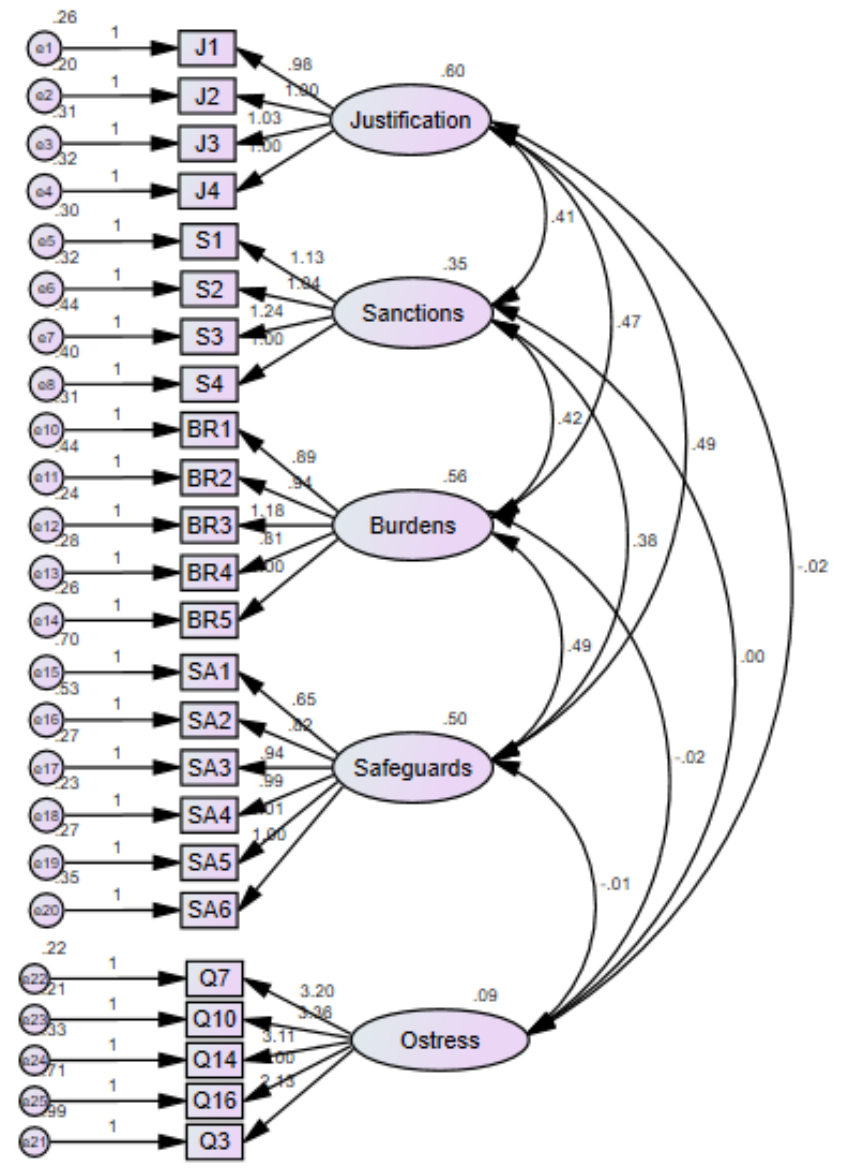

Figure 2.Confirmatory Factor Analysis Model

Table 3.Reliability \& Validity

\begin{tabular}{|c|c|c|c|c|c|c|c|c|}
\hline \multicolumn{3}{|c|}{ Factors } & Factor & S.E & Square & & CR ( $(\alpha)$ & AVE \\
\hline $\mathrm{J} 4$ & $<--$ & Justification & 0.648025 & 0.323 & 0.648025 & \multirow{4}{*}{11.00912} & \multirow{4}{*}{0.91} & \multirow{4}{*}{0.69} \\
\hline $\mathrm{J} 3$ & $<--$ & Justification & 0.670761 & 0.312 & 0.670761 & & & \\
\hline $\mathrm{J} 2$ & <--- & Justification & 0.746496 & 0.203 & 0.746496 & & & \\
\hline $\mathrm{J} 1$ & <--- & Justification & 0.6889 & 0.259 & 0.6889 & & & \\
\hline BR5 & $<--$ & Burdens & 0.683929 & 0.257 & 0.683929 & \multirow[t]{5}{*}{15.53936} & \multirow[t]{5}{*}{0.91} & \multirow[t]{5}{*}{0.62} \\
\hline BR4 & $\begin{array}{l}<-- \\
\end{array}$ & Burdens & 0.565504 & 0.279 & 0.565504 & & & \\
\hline BR3 & $<--$ & Burdens & 0.763876 & 0.238 & 0.763876 & & & \\
\hline BR1 & $<--$ & Burdens & 0.583696 & 0.313 & 0.583696 & & & \\
\hline BR2 & $<--$ & Burdens & 0.525625 & 0.444 & 0.525625 & & & \\
\hline S4 & <--- & Sanctions & 0.466489 & \begin{tabular}{|l|}
0.399 \\
\end{tabular} & 0.466489 & \multirow[t]{4}{*}{8.625969} & \multirow[t]{4}{*}{0.86} & \multirow[t]{4}{*}{0.54} \\
\hline S3 & $<--$ & Sanctions & 0.549081 & 0.438 & 0.549081 & & & \\
\hline S2 & $<--$ & Sanctions & 0.543169 & 0.321 & 0.543169 & & & \\
\hline S1 & $<--$ & Sanctions & 0.602176 & 0.297 & 0.602176 & & & \\
\hline
\end{tabular}




\begin{tabular}{|c|c|c|c|c|c|c|c|c|}
\hline SA6 & $\begin{array}{l}<-- \\
\end{array}$ & Safeguards & 0.588289 & 0.35 & 0.588289 & \multirow[t]{6}{*}{18.4728} & \multirow[t]{6}{*}{0.89} & \multirow[t]{6}{*}{0.53} \\
\hline SA5 & $<--$ & Safeguards & 0.652864 & 0.27 & 0.652864 & & & \\
\hline SA4 & $<--$ & Safeguards & 0.680625 & 0.231 & 0.680625 & & & \\
\hline SA3 & $<---$ & Safeguards & 0.619369 & 0.272 & 0.619369 & & & \\
\hline SA2 & $\begin{array}{l}<-- \\
\end{array}$ & Safeguards & 0.393129 & 0.526 & 0.393129 & & & \\
\hline SA1 & <--- & Safeguards & 0.234256 & 0.701 & 0.234256 & & & \\
\hline Q16 & $\begin{array}{l}<-- \\
\end{array}$ & O stress & 0.116281 & 0.711 & 0.116281 & \multirow[t]{5}{*}{12.68072} & \multirow[t]{5}{*}{0.84} & \multirow[t]{5}{*}{0.56} \\
\hline Q14 & $<--$ & O stress & 0.734449 & 0.326 & 0.734449 & & & \\
\hline Q10 & $<--$ & O stress & 0.835396 & 0.207 & 0.835396 & & & \\
\hline Q7 & $<--$ & O stress & 0.811801 & 0.223 & 0.811801 & & & \\
\hline Q3 & $\begin{array}{l}<-- \\
\end{array}$ & O stress & 0.300304 & 0.991 & 0.300304 & & & \\
\hline
\end{tabular}

Reliability $(\mathrm{CR}-(\alpha))$ is $>0.9$ is 'Excellent' \& $>0.8$ is 'Good'.

Validity (AVE) is $>0.5$ is acceptable and valid.

$\mathrm{N}=159$ Respondents.

Source: Survey.

Confirmatory Factor analysis was carried out with the help of 'maximum likelihood' extraction method. In the measuring section, the relationship between the items and the related structure is clarified in the factor loading of items. This value supports the reliability of the structure using measuring. As it can be seen in Table -3 , all CR value of factors is greater than $0.8 \& 0.9$ hence the overall fit is acceptable. The reliability of the construct is assessed based on Cronbach's alpha. Similarly to check the validity of the item AVE have been extracted and it has been observed that all values are greater than 0.5 . So from the above measurement, it can be stated that the measurement is valid and reliable.

\section{Measurement Model (SEM)}

Table $4 \&$ Figure 3 represents the data on regression weights and SEM modelling respectively. The conceptual model is investigated by using structural equation modelling and the impact of the construct has been tested accordingly. In addition, investigating the measuring and the structural section of model judgment is made based on the fitness indicator of the model.

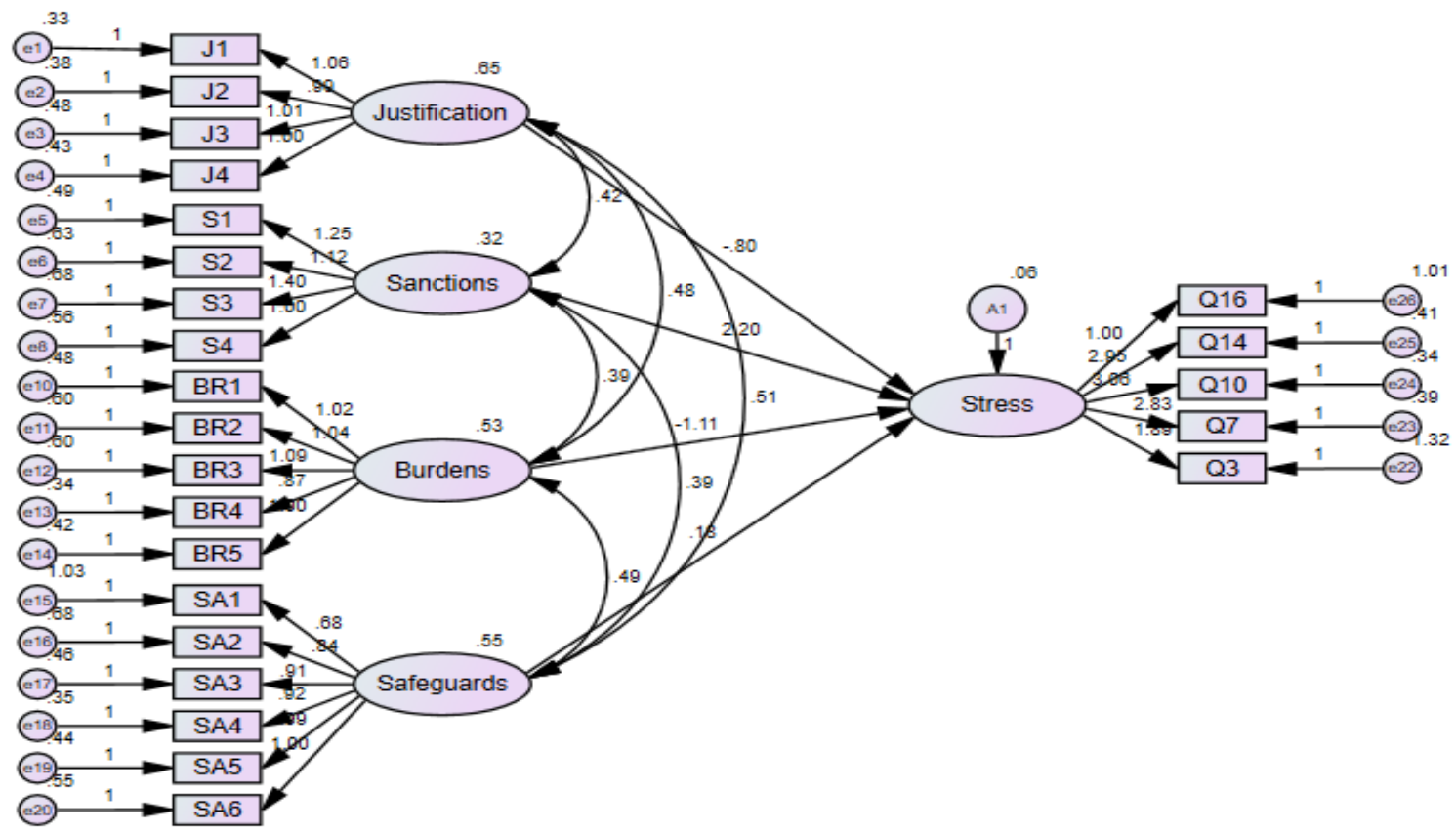

Figure 3.Structural Equation Modelling 
Table 4.Regression Weights

\begin{tabular}{|l|l|l|l|l|l|l|l|}
\hline & & & Estimate & S.E. & C.R. & P & Label \\
\hline Stress & $<---$ & Justification & -.799 & .885 & -.904 & .366 & \\
\hline Stress & $<---$ & Sanctions & 2.199 & 3.010 & .730 & .465 & \\
\hline Stress & $<---$ & Burdens & -1.109 & 1.436 & -.772 & .440 & \\
\hline Stress & $<---$ & Safeguards & .178 & .478 & .372 & .710 & \\
\hline
\end{tabular}

The model tested subsumed the specified relationship proposed in the hypotheses. The overall fit indicates that the structural model reveals a Chi-square of 1.650 with 242 degree of freedom. For this model, $\mathrm{RMSEA}=0.064, \mathrm{RMR}=0.064, \mathrm{NFI}=0.822, \mathrm{GFI}=0.826, \mathrm{AGFI}=0.785, \mathrm{PGFI}=0.667$, $\mathrm{PNFI}=0.721$, which are acceptable.

The analysis of SEM on the proposed model has generated results which are indicated in Figure $3 \&$ Table 5.

Table 5.Model Fit Summary

\begin{tabular}{|l|l|l|l|}
\hline Model Fit Index & Recommended Value & Structure Model & Remarks \\
\hline$X^{2} / \mathrm{df}$ & $\leq 5$ & 1.650 & Accepted Fit \\
\hline RMSEA & $\leq .08$ & .064 & Excellent Fit \\
\hline RMR & $<.08$ & .064 & Excellent Fit \\
\hline NFI & $>.90$ & .822 & Accepted Fit \\
\hline GFI & $>.80$ & .826 & Accepted Fit \\
\hline AGFI & $>.80$ & .785 & Accepted Fit \\
\hline PGFI & $>.50$ & .667 & Excellent Fit \\
\hline PNFI & $>.50$ & .721 & Excellent Fit \\
\hline
\end{tabular}

Note: RMSEA = Root Mean Square Error of Approximation, RMR = Root Mean Square Residual NFI = Normed Fit Index, GFI = Goodness of Fit Index, AGFI = Adjusted Goodness of Fit Index, PGFI = Parsimony Goodness of Fit Index, PNFI = Parsimony Adjusted Measures Index.

For the above measurement of model fit summary in table 5, it has been observed that the model fit can be accepted for assuming the results for testing the hypotheses. By observing the regression estimate values of table 4 it can be stated that there is no significant impact of quarantine on occupational stress. So, the proposed hypotheses are rejected.

\section{Perception about Quarantine}

Table-6 represents the perception of quarantine among the respondents as mentioned below:

Table 6.People's attitudes toward quarantine (Qx) by a factor

\begin{tabular}{|l|l|l|l|l|l|l|}
\hline & $\begin{array}{l}\text { Strongly } \\
\text { Agree }\end{array}$ & Agree & Neutral & Disagree & $\begin{array}{l}\text { Strongly } \\
\text { Disagree }\end{array}$ \\
\hline Justification & $17.0 \%$ & $37.7 \%$ & $30.8 \%$ & $10.1 \%$ & $4.4 \%$ \\
\hline $\begin{array}{l}\text { Health Department should have the power } \\
\text { to order people into QxL during outbreaks. }\end{array}$ & $18.9 \%$ & $\begin{array}{l}46.5 \\
\%\end{array}$ & $20.1 \%$ & $11.3 \%$ & $3.1 \%$ \\
\hline $\begin{array}{l}\text { Qx is the right way to stop spreading of the } \\
\text { outbreak of infectious disease. }\end{array}$ & $28.3 \%$ & $\begin{array}{l}42.1 \\
\%\end{array}$ & $17.0 \%$ & $8.2 \%$ & $4.4 \%$ \\
\hline $\begin{array}{l}\text { If someone is given a Qx order by the } \\
\text { Public Health Department, they should } \\
\text { follow it no matter what else is going on in } \\
\text { their life at work or home }\end{array}$ & $15.7 \%$ & $41.5 \%$ & $25.8 \%$ & $12.6 \%$ & $4.4 \%$ \\
\hline $\begin{array}{l}\text { If I go into Qx, my family/friends/ } \\
\text { community will be protected from } \\
\text { becoming infected. }\end{array}$ & & & & & \\
\hline Sanctions & & & & \\
\hline
\end{tabular}




\begin{tabular}{|c|c|c|c|c|c|}
\hline $\begin{array}{l}\text { People who break Qx orders intentionally } \\
\text { should face legal penalties like a fine or jail. }\end{array}$ & $20.8 \%$ & $39.0 \%$ & $27.7 \%$ & $10.1 \%$ & $2.5 \%$ \\
\hline $\begin{array}{l}\text { Government should be able to lock-up } \\
\text { people if they fail to obey Qx orders }\end{array}$ & $15.7 \%$ & $33.3 \%$ & $35.2 \%$ & $11.9 \%$ & $3.8 \%$ \\
\hline $\begin{array}{l}\text { Health Department should use electronic } \\
\text { bracelets and in-home surveillance cameras } \\
\text { for people who disobey Qx orders }\end{array}$ & $13.8 \%$ & $33.3 \%$ & $23.3 \%$ & $23.3 \%$ & $6.3 \%$ \\
\hline $\begin{array}{l}\text { Health Department should provide } \\
\text { immediate medical back-ups for infected } \\
\text { patients. }\end{array}$ & $32.1 \%$ & $43.4 \%$ & $15.1 \%$ & $8.8 \%$ & $0.6 \%$ \\
\hline \multicolumn{6}{|l|}{ Burdens } \\
\hline $\begin{array}{l}\text { Health Department needs to explain to } \\
\text { everyone why they should be allowed to use } \\
\text { Qx. }\end{array}$ & $14.5 \%$ & $42.1 \%$ & $23.9 \%$ & $17.0 \%$ & $2.5 \%$ \\
\hline $\begin{array}{l}\text { Government should pay for doctors, nurses } \\
\text { and counsellors to help people who are in } \\
\text { Qx. }\end{array}$ & $15.7 \%$ & $35.2 \%$ & $31.4 \%$ & $11.3 \%$ & $6.3 \%$ \\
\hline $\begin{array}{l}\text { Health Department should ensure that } \\
\text { people have food and shelter while in Qx } \\
\text { and pay for it with public money if needed. }\end{array}$ & $37.7 \%$ & $33.3 \%$ & $16.4 \%$ & $8.8 \%$ & $3.8 \%$ \\
\hline $\begin{array}{l}\text { Government should pay for support groups } \\
\text { so that people coming out of Qx have } \\
\text { someone to talk to about it. }\end{array}$ & $17.0 \%$ & $45.9 \%$ & $27.7 \%$ & $9.4 \%$ & - \\
\hline $\begin{array}{l}\text { People in Qx should get money from the } \\
\text { government to pay for workdays lost or } \\
\text { missed. }\end{array}$ & $23.9 \%$ & $47.2 \%$ & $17.0 \%$ & $10.1 \%$ & $1.9 \%$ \\
\hline \multicolumn{6}{|l|}{ Safeguards } \\
\hline $\begin{array}{l}\text { Health Department should ensure that } \\
\text { facilities should be equally provided in } \\
\text { irrespective of one's social status. }\end{array}$ & $16.4 \%$ & $40.9 \%$ & $23.9 \%$ & $10.7 \%$ & $8.2 \%$ \\
\hline $\begin{array}{l}\text { It is reasonable for some rights to be taken } \\
\text { away during the outbreak of an infectious } \\
\text { disease. }\end{array}$ & $20.8 \%$ & $35.2 \%$ & $27.7 \%$ & $14.5 \%$ & $1.9 \%$ \\
\hline $\begin{array}{l}\text { People who disagree with their } \mathrm{Qx} \text {. the } \\
\text { order should request for a further review to } \\
\text { have an early release. }\end{array}$ & $22.6 \%$ & $49.1 \%$ & $17.0 \%$ & $9.4 \%$ & $1.9 \%$ \\
\hline $\begin{array}{l}\text { Government should ensure proper health } \\
\text { care facilities for the people at Qx. }\end{array}$ & $17.0 \%$ & $49.7 \%$ & $24.5 \%$ & $6.3 \%$ & $2.5 \%$ \\
\hline $\begin{array}{l}\text { Strict Law \& Order should be imposed to } \\
\text { control the spreading of the diseases } \\
\text { amongst the community. }\end{array}$ & $18.9 \%$ & $45.3 \%$ & $24.5 \%$ & $7.5 \%$ & $3.8 \%$ \\
\hline $\begin{array}{l}\text { Government should be responsible to make } \\
\text { sure of the availability of basic necessity } \\
\text { items in the market (Groceries \& } \\
\text { Medicines). }\end{array}$ & $11.9 \%$ & $35.2 \%$ & $28.3 \%$ & $20.8 \%$ & $3.8 \%$ \\
\hline
\end{tabular}

$\mathrm{N}=159$ Respondents, Source: Survey.

From the above table, it is quite evident that the majority of the respondent's agreed with the items under the different factors. This indicates that the attitude of the maximum respondents towards quarantine are positive which means they support quarantine during this pandemic outbreak of Covid19 in India. 


\section{Discussion and Conclusion}

The relationship between occupational stress by the people's perception of quarantine was not significant. Hence, the hypothesis for the present study based on the results of structural equation modelling has been rejected. It is very much true that Corona virus disease 2019, commonly known as COVID-19 is an infectious disease spreading primarily through droplets of saliva or discharge from the nose when an infected person coughs or sneezes. Due to this pandemic disease, the entire industrial and commercial activities of an area, a state, country or many countries of the world has come to standstill and got paralysed. It is to be admitted in common parlance that an employee in quarantine might develop occupational stress on the following grounds:

(i) The level of occupational stress is more as people have to work from their home where assignments and training for self-development take place continuously.

(ii) The employee gets frightened because of the possibility that his / her superior or employer might impose disciplinary action against him/her if not attended the work.

(iii) There is also a high probability that the peers of an employee might criticize or work against $\mathrm{him} / \mathrm{her}$ if the later remains absent, tardy or disengaged.

(iv) There is a great chance of an employee getting scared of losing his / her job on the disciplinary ground due to acute absence, tardiness, low performance, disengagement etc. Moreover, an employee might develop a feeling of losing jobs or rewards including pay cuts resulting from dissolution/downsizing of business activities. These lead to high job security stress.

(v) Recession in the economy of the country has affected its labour market.

(vi) Work-life balance is also not that much effective as living in quarantine affects the people psychologically.

(vii) Health Stress is also another factor that has affected effectively the occupational stress in a negative manner due to the pandemic caused by the outbreak of COVID -19 in India.

It cannot be denied that employees are the lifeblood of any organization and hardly there is any organization which are an employee-less. Employees are human resources which are undoubtedly unique when compared with all other resources such as financial, physical and intangible. It is to be agreed that all other resources make things possible but only human resources make things happen. This is the uniqueness and beauty of human resources in any organization. Last but not the least, it would not be out of place to mention that "Doing the best at this moment puts you in the best place for the next moment".

The study was limited to India only. Therefore, the findings and implications of the study are restricted to the specific geographical area, social, cultural and economic aspects. They cannot be generalized to other regions. Another limitation can be sample size as a large sample size could have provided much better results. Hence, future studies can be conducted with more variables and geographical regions.

\section{References}

1. Zhu N, Zhang D, Wang W, Li X, Yang B, Song J et al. A Novel Coronavirus from Patients with Pneumonia in China, 2019. N Engl J Med 2020; 382:727-33.

2. Wang C, Horby PW, Hayden FG, Gao GF. A novel coronavirus outbreak of global health concern. Lancet 2020; 395(10223): 470-3.

3. Huang C, Wang Y, Li X, et al. Clinical features of patients infected with 2019 novel coronavirus in Wuhan, China. Lancet 2020; 395(10223): 497-506.

4. WHO. Coronavirus disease 2019 (COVID-19) Situation Report-69 https://wwwwhoint/ docs/default-source/coronaviruse/situation-reports/20200329-sitrep-69-covid-19pdf?Sfvrs $\mathrm{n}=8 \mathrm{~d} 6620 \mathrm{fa} \_82020$.

5. Wu Z, McGoogan JM. Characteristics of and Important Lessons from the Coronavirus Disease 2019 (COVID-19) Outbreak in China: Summary of a Report of 72314 Cases from the Chinese Center for Disease Control and Prevention. Jama 2020. 
6. Guan WJ, Ni ZY, Hu Y, Liang WH, Ou CQ, He JX et al. Clinical Characteristics of Coronavirus Disease 2019 in China. N Engl J Med 2020.

7. Wu P, Fang Y, Guan Z, et al. The psychological impact of the SARS epidemic on hospital employees in China: exposure, risk perception, and altruistic acceptance of risk. Can J Psychiatry 2009; 54: 302-11.

8. Avey, J. B., Luthans, F., Jensen, S. M. (2009). Psychological capital: A positive resource for combating employee stress and turnover. Human Resource Management, 48, 677-693.

9. Arnetz, B. B. (2006). Stress in health and disease. In Arnetz, B. B., Ekman, R. (Eds.), Stress-Why managers should care (pp. 92-121). Weinheim, Germany: Wiley-VCH Verlag GmbH \& Co. KGaA.

10. Darr, W., Johns, G. (2008). Work strain, health, and absenteeism: A meta-analysis. Journal of Occupational Health Psychology, 13, 293-318.

11. Flanagan, N. A., Flanagan, T. J. (2002). An analysis of the relationship between job satisfaction and job stress in correctional nurses. Research in Nursing \& Health, 25, 282-294.

12. Campbell, F. (2006) Occupational Stress in the Construction Industry-A Survey, The Chartered Institute of Building (CIOB) Survey, Ascot Berkshire.

13. Hawryluck, L., Gold, W. L., Robinson, S., Pogorski, S., Galea, S., \& Styra, R. (2004). SARS control and psychological effects of quarantine, Toronto, Canada. Emerging infectious diseases, 10(7), 1206-1212. https://doi.org/10.3201/eid1007.030703.

14. Kitchenham, B. (2004) Procedures for Performing Systematic Reviews. Keele University, Keele, 33.

15. Cohen, S., Kamarck, T., and Mermelstein, R. (1983). The PSS Scale is reprinted with permission of the American Sociological Association, from A global measure of perceived stress. Journal of Health and Social Behavior, 24, 386-396.

16. Cohen, S. and Williamson, G. Perceived Stress in a Probability Sample of the United States. Spacapan, S. and Oskamp, S. (Eds.) The Social Psychology of Health. Newbury Park, CA: Sage, 1988.

17. Tracy, C. S., Rea, E., \& Upshur, R. E. (2009). Public perceptions of quarantine: community-based telephone survey following an infectious disease outbreak. BMC Public Health, 9(1), 470.

18. Brooks, S. K., Webster, R. K., Smith, L. E., Woodland, L., Wessely, S., Greenberg, N., \& Rubin, G. J. (2020). The psychological impact of quarantine and how to reduce it: rapid review of the evidence. The Lancet.

19. Reynolds, D. L., Garay, J. R., Deamond, S. L., Moran, M. K., Gold, W., \& Styra, R. (2008). Understanding, compliance and psychological impact of the SARS quarantine experience. Epidemiology \& Infection, 136(7), 997-1007.

20. Ho, C. S., Chee, C. Y., \& Ho, R. C. (2020). Mental health strategies to combat the psychological impact of COVID-19 beyond paranoia and panic. Ann Acad Med Singapore, 49(1), 1-3.

21. Nguyen, V. (2020). Human capital, capital structure choice and firm profitability in developing countries: An empirical study in Vietnam. Accounting, 6(2), 127-136. http:// dx.doi.org/10.5267/j.ac.2019.11.003.

22. Nguyen, V.C. and Do, T.T. (2020). Impact of Exchange Rate Shocks, Inward FDI and Import on Export Performance: A Cointegration Analysis. Journal of Asian Finance, Economics and Business, 7 (4), 163-171. DOI: https://doi.org/10.13106/jafeb.2020. vol7. no4.163. 